\title{
ASUPAN LEMAK SEBAGAI FAKTOR DOMINAN TERHADAP OBESITAS SENTRAL PADA WANITA
}

\author{
Fat Intake As A Dominant Factor of Central Obesity Among Women
}

\author{
Triyanti Triyanti ${ }^{l}$, Putri Ardila $^{l)}$ \\ ${ }^{1)}$ Departemen Gizi Fakultas Kesehatan Masyarakat, Universitas Indonesia \\ triyantigizi@gmail.com
}

\begin{abstract}
Central Obesity is associated with cardiovascular disease and myocardial infarct. There are strong indications both cardiovascular and myocardial infark associated with increased mortality. The incidence of obesity is increasingly not only cities but also in villages. This study set out to evaluate the prevalence of central obesity and some related factors among adult women in rural area. The sample included 120 adult women, aged 20-59 years, residing the rural area in Ketug Village, Purworejo, Central Java. Simple random sampling used to collected data. Sociodemographic data were collected using the questionnaire and waist circumference was measured. According to cut off point of waist circumference $(\geq 80 \mathrm{~cm}$ ), the prevalence of central obesity was $47,5 \%$. Bivariate analysis revealed that central obesity was significantly associated with these factors: age, energy intake, fat intake, carbohydrate intake, central obesity history, and parity. Based on logistic regression analysis, the factor that was most closely associated with central obesity was fat intake (OR: 9,494, CI:2,5-35,1).
\end{abstract}

Keywords: adult women, central obesity, fat intake, rural area

\begin{abstract}
ABSTRAK
Obesitas sentral berhubungan dengan penyakit kardiovaskular dan infark mikardium. Keduanya berhubungan erat dengan kematian. Prevalensi obesitas sentral terus meningkat tidak hanya di perkotaan tetapi juga pedesaan. Tujuan dari penelitian ini adalah untuk mengetahui prevalensi obesitas sentral dan beberapa faktor yang terkait di kelomok perempuan dewasa. Penelitian ini melibatkan 120 orang perempuan dewasa berusia 20-59 tahun sebagai sampel penelitian di desa Ketug, Purworejo, Jawa Tengah. Data sosiodemografi dikumpulkan menggunakan kuesioner dan lingkar pinggang diukur langsung oleh peneliti. Berdasarkan ambang batas $(\geq 80 \mathrm{~cm})$, didapatkan prevalensi obesitas sentral sebesar 47,5\%. Berdasarkan analisis bivariat terdapat hubungan yang bermakna antara obesitas sentral dengan faktor umur, asupan energi, asupan lemak, asupan karbohidrat, riwayat obesitas sentral orang tua, dan jumlah anak yang dilahirkan. Berdasarkan analisis regresi logistik ganda didapatkan asupan lemak sebagai faktor dominan terhadap obesitas sentral.
\end{abstract}

Kata kunci: asupan lemak, obesitas sentral, perempuan dewasa, pedesaan

\section{PENDAHULUAN}

Lingkar pinggang yang melebihi normal atau obesitas sentral mempunyai hubungan erat dengan beberapa penyakit seperti kardiovaskular yang menyebabkan kematian (WHO,2008). Sementara studi lainnya menunjukkan hubungan yang erat antara obesitas sentral dengan diabetes melitus tipe 2, hipertensi, gangguan fungsi

hati dan kematian (Direk,et al.,2013).

Berdasarkan data Riskesdas 2013, dan 2018 prevalensi obesitas sentral di Indonesia mengalami peningkatan dari $26,6 \%$ menjadi 31\%. . Berdasarkan data Riskesdas 2013, dan 2018 prevalensi obesitas sentral di Jawa Tengah mengalami peningkatan dari $24,7 \%$ 
menjadi sekitar 28\%. Berdasarkan karakteristik jenis kelamin baik di tingkat nasional maupun di Jawa Tengah prevalensi obesitas sentral banyak diderita oleh kelompok perempuan. Obesitas sentral baik pada perempuan maupun laki-laki muncul karena akumulasi lemak di jaringan lemak abdominal. Hal ini diperngaruhi oleh beberapa faktor seperti umur, tingkat pendidikan, tingkat pengetahuan gizi, pekerjaan, riwayat obesitas sentral orang tua, status pernikahan, asupan energi harian, asupan serat dan aktivitas fisik. Khusus pada perempuan jumlah anak yang dilahirkan, penggunaan kontrasepsi hormonal, dan status menopause juga berpengaruh pada obesitas sentral (Tchernof,2013; Gravena, et al,2013); Tzotzas, et al,2010; Sugiharti, et al,2005).

Negara berkembang seperti Indonesia telah mengalami transisi gizi yang

\section{METODE}

\section{Desain, Tempat dan Waktu}

Desain penelitian ini adalah potong lintang atau cross-sectional. Penelitian dilakukan di Desa Ketug, Kecamatan Butuh, Kabupaten Purworejo pada bulan April 2015.

\section{Jumlah dan cara pengambilan subjek}

Sampel penelitian adalah perempuan dewasa berumur 20-59 tahun di Desa Ketug, disebabkan oleh industrialisasi dan migrasi. Hal ini mengakibatkan perubahan pola diet, aktivitas fisik, dan kesehatan secara umum yang terjadi tidak hanya di perkotaan namun juga di pedesaan. Mekanisasi atau penggunaan alat alat canggih di sektor pertanian mengakibatkan tingkat aktifitas penduduk desa menurun. Meningkatnya ketersediaan makanan tinggi lemak dan gula juga menjadi faktor penyebab transisi gizi di pedesaan yang pada akhirnya meningkatkan kejadian obesitas sentral. Saat ini masih terbatasnya penelitian terkait obesitas sentral pada kelompok wanita dewasa di pedesaan sehingga perlu dilakukan penelitian dengan tujuan mendapatkan gambaran kejadian obesitas dan mengetahui faktor dominan yang berhubungan dengan obesitas sentral pada wanita dewasa di pedesaan.

Kecamatan butuh, Purworejo yang berjumlah 120 orang. Responden ditentukan dengan menggunakan metoda simple random sampling berdasarkan daftar penduduk perempuan di desa tersebut. Sebagai kriteria inklusi adalah perempuan dewasa yang terdaftar sebagai warga desa Ketug, Kecamatan Butuh, Kabupaten Purworejo, Jawa Tengah dan dapat berdiri tegak. Sementara kriteria eksklusi adalah 
J.Gipas, November 2019, Volume 3 Nomor 2 ISSN 2599-0152 eISSN 2599-2465 http://jos.unsoed.ac.id/index.php/jgps

perempuan yang sedang hamil. Variabel yang dikumpulkan dalam penelitian ini adalah obesitas sentral sebagai variabel dependen dan variabel independen yang dikelompokkan menjadi tiga kelompok yaitu: sosiodemografi (umur, tingkat pendidikan, tingkat pengetahuan gizi, pekerjaan, status pernikahan), faktor yang dapat dimodifikasi (aktivitas fisik, asupan energi, asupan karbohidrat, asupan protein, asupan lemak, asupan serat), faktor lain (riwayat obesitas sentral orang tua, jumlah anak yang dilahirkan, status menopause, penggunaan kontrasepsi hormonal). Data dikumpulkan dengan menggunakan kuesioner terstruktur yang telah dilakukan uji coba serta pengukuran lingkar pinggang. Pengukuran lingkar pinggang dilakukan dengan menggunakan pita ukur sebanyak dua kali. Pengukuran lingkar pinggang diukur tepat di titik tengah antara tulang rusuk dan tulang iliac responden. Data asupan makanan dikumpulkan dengan wawancara terhadap responden menggunakan formulir 24 hour recall selama dua kali di pada hari biasa (weekday) dan hari libur (weekend). Food model digunakan untuk mendapatkan gambaran jumlah makanan yang dikonsumsi. Untuk mengukur tingkat aktivitas fisik menggunakan kuesioner GPAQ (Global
Physical Activity Questionanaire) (WHO, 2011)

Pengumpul data adalah peneliti dan mahasiswi yang berlatar belakang gizi. Sebelum pengumpulan data dilakukan pelatihan yang bertujuan untuk menyamakan persepsi antara peneliti dengan pengumpul data. Pengumpulan data dilakukan dengan cara door to door atau mendatangi tempat tinggal masing-masing yamg terpilih saat randomisasi yang sebelumnya menandatangi lembar persetujuan menjadi responden.

\section{Analisis data}

Untuk memudahkan analisis data maka dilakukan pengelompokkan data tiap variabel. Data hasil ukur lingkar pinggang dikelompokkan menjadi obesitas sentral jika lingkar pinggang $\geq 80 \mathrm{~cm}$, dan tidak obesitas sentral jika lingkar pinggang $<80 \mathrm{~cm}$. (WHO,2008). Variabel umur dikelompokkan menjadi dewasa muda (umur 20-39 tahun) dan umur dewasa tua (umur 40-59 tahun) (Brown,2011). Tingkat pendidikan dikelompokkan menjadi tingkat pendidikan rendah (lama sekolah kurang dari 9 tahun) dan pendidikan tinggi (lama sekolah $\geq 9$ tahun). Tingkat pengetahuan gizi dikelompokkan berdasarkan jumlah nilai yang diperoleh menjadi rendah jika nilai kurang dari rerata $(<$ rerata) dan tinggi jika 
nilai lebih atau sama dari rerata ( $\geq$ rerata) (Kantachuvessiri,2005). Jenis pekerjaan dikelompokkan menjadi ringan dan berat (WHO,2011). Status pernikahan dikelompokkan menjadi menikah dan belum menikah atau janda (Tzotzas,2010). Riwayat obesita sentral dikelompokkan menjadi ya (jika mempunyai salah satu atau kedua orang tua obesitas sentral) dan tidak (jika tidak mempunyai salah satu atau kedua orang tua obesitas sentral). Asupan energi dikelompokkan menjadi asupan energi tinggi (asupan $>100 \%$ AKG) dan rendah $(\leq 100 \%$ AKG). Asupan karbohidrat dikelompokkan menjadi tinggi (asupan > 100\% AKG) dan rendah $(\leq 100 \%$ AKG). Asupan protein dikelompokkan mejadi tinggi (asupan $>80 \%$ $\mathrm{AKG})$ dan rendah $(\leq 80 \% \mathrm{AKG})$. Asupan lemak dikelompokkan menjadi tinggi (asupan $\geq 110 \% \mathrm{AKG})$ dan rendah $(<110 \%$ AKG). Asupan serat dikelompokkan menjadi tinggi (asupan $\geq$ rerata) dan rendah ( $<$ rerata).

\section{HASIL DAN PEMBAHASAN}

Sejumlah 120 wanita terlibat sebagai responden dengan rerata $\pm \mathrm{SD}$ umur yaitu $43,03 \pm 10,83$ tahun dengan umur termuda 20 tahun dan tertua 59 tahun. Sebagian besar $(53,3 \%)$ berpendidikan rendah $(<9$ tahun), dengan persentase terbanyak berpendidikan tamat sekolah dasar (40\%), tingkat pekerjaan
Aktivitas fisik dikelompokkan menjadi cukup ( $\geq$ rerata) dan kurang $<$ rerata). Jumlah anak dikelompokkan menjadi banyak $(\geq 3$ orang) dan sedikit ( $<3$ orang) (Gravena et al,2014). Status menopause dikelompokkan menjadi ya dan tidak (Heidari et al,2010). Penggunaan kontrasepsi hormonal dikelompokkan menjadi ya dan tidak (Sugiharti,2005). Data diolah dengan menggunakan program pengolah data setelah melalui proses cleaning.

Analisis data univariat menggunakan distribusi frekuensi untuk mendapatkan gambaran semua variabel yang diteliti. Uji bivariat menggunakan kai kuadrat atau chi square untuk mendapatkan hubungan antara variabel independen dengan dependen. Analisis multivariat menggunakan regresi logistik ganda untuk mendapatkan variabel yang paling dominan berhubungan dengan obesitas sentral.

ringan (53,3\%), menikah (92,5\%), berprofesi sebagai ibu rumah tangga (47,5\%), mempunyai tingkat aktivitas ringan (53,3\%). Umumnya tingkat pengetahuan gizi masih rendah yang ditandai dengan nilai rerata \pm SD sebesar $57,33 \pm 1,47$. Sejumlah $47,5 \%$ responden melahirkan anak $\geq 3$ orang, $31,7 \%$ menapause, $30,8 \%$ mempunyai riwayat 
orang tua obesitas saentral. Sebanyak 37,5\% responden menggunakan alat kontrasepsi hormonal atau pernah menggunakannya dalam setahun terakhir. Dari responden yang menggunakan alat kontrasepsi hormonal, 56\% menggunakan suntik.

Hasil analisis data konsumsi menunjukkan rerata \pm SD energi sebesar $1813 \pm 319,34$ kkal. Rerata \pm SD asupan protein yaitu $41,57 \pm 9,95$ gram. Sementara rerata asupan \pm SD lemak sebesar $66,21 \pm 13,87$ gram. Untuk rerata \pm SD asupan karbohidrat yaitu $267,33 \pm 48,63$ gram. Asupan serat masih rendah dengan rerata \pm SD sebesar 10,29 $\pm 2,6$ gram.

Nilai rerata $\pm S D$ lingkar pinggang adalah 79,99 $\pm 1,07 \mathrm{~cm}$ dengan lingkar terendah $60,60 \mathrm{~cm}$ dan tertinggi $124,65 \mathrm{~cm}$. Angka ini hanya sedikit lebih kecildari cut off point obesitas sentral perempuan dewasa dari WHO ( $\geq 80 \mathrm{~cm}$ ). Berdasarkan kategori WHO dengan cut off point $80 \mathrm{~cm}$, menunjukkan $47,5 \%$ responden mengalami obesitas sentral. Hal ini menunjukkan angka obesitas sentral yang termasuk tinggi. Hasil penelitian ini mendapatkan angka obesitas sentral yang lebih tinggi jika dibandingkan dengan angka Nasional $31 \%$ (Riskesdas,2018).

Obesitas sentral adalah obesitas di tubuh bagian atas karena akumulasi lemak di bagian atas atau sering disebut obesitas tipe apel. Perempuan Asia diketahui cenderung mempunyai lemak abdominal lebih besar daripada Ras Kaukasia dan Afrika-Amerika dengan indeks massa tubuh yang sama. Obesitas sentral dapat diukur dengan lingkar pinggang. Lingkar pinggang merupakan alat ukur yang baik dan mudah untuk mengukur lemak abdominal. Hasil studi di Korea menunjukkan hasil pengukuran mempunyai korelasi yang positif dengan hasil pengukuran lemak abdominal menggunakan metode Dual Energy E-ray Absorptiometry (DXA) (Hwang,2008).

Lingkar pinggang mempunyai hubungan yang kuat dengan risiko penyakit kardiovaskular. Hal ini didasarkan pada peningkatan jaringan lemak visceral yang berhubungan dengan beberapa penyimpangan komponen metabolik seperti menurunnya toleransi glukosa, berkurangnya sensitifitas insulin, dan penyimpangan profil lipid (HDL,LDL, dan trigliserida) dari nilai normal. Komponen tersebut merupakan faktor risiko diabetes tipe 2 dan penyakit kardiovaskular lainnya (IDF,2006). Risiko penyakit kardiovaskular di populasi Asia cenderung sudah meningkat dengan lingkar pinggang yang lebih kecil daripada populasi Eropa dan Amerika. Berdasarkan pertimbangan tersebut, WHO 
J.Gipas, November 2019, Volume 3 Nomor 2 ISSN 2599-0152 eISSN 2599-2465 http://jos.unsoed.ac.id/index.php/jgps

merekomendasikan batas lingkar pinggang untuk kategori obesitas sentral di Asia Pasifik untuk pria $\geq 90 \mathrm{~cm}$ dan wanita $\geq 80 \mathrm{~cm}$. (WHO,2008).

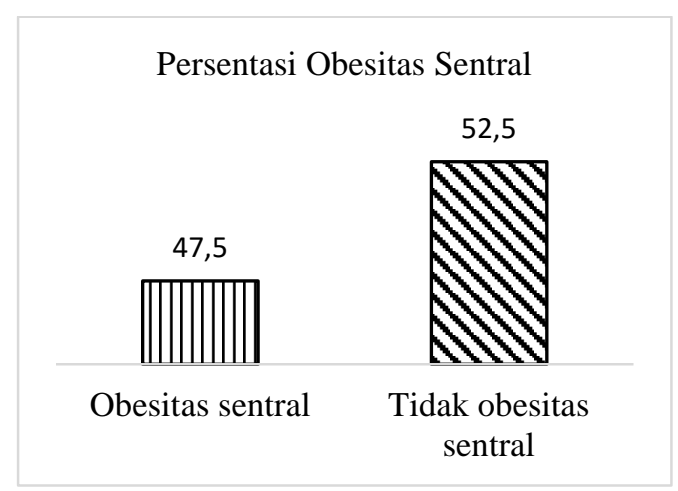

Gambar 1. Presentasi Obesitas Sentral

Berdasarkan hasil bivariat menunjukkan tedapat hubungan yang bermakna antara variabel umur, asupan energi, asupan lemak, asupan karbohidrat, riwayat obesitas sentral orang tua dan jumlah anak yang dilahirkan dengan obesitas sentral. Hasil penelitian menunjukkan kelompok dewasa akhir (40-59 tahun) mempunyai peluang 5,505 kali mengalami obesitas sentral dibandingkan kelompok umur dewasa awal (20-39 tahun). Hasil penelitian ini sesuai dengan teori bahwa bertambahnya umur perempuan berhubungan dengan peningkatan jaringan lemak abdominal yang dapat memicu obesitas sentral (Techernof,2013). Hasil penelitian ini sejalan dengan studi Bhatta,et al (2014) pada wanita 18-65 tahun di Bhutan yang mendapatkan hubungan yang bermakna antara umur dengan obesitas sentral dengan peningkatan odds sebesar 0,10 terjadi setiap umur seseorang meningkat satu tahun.

Sebagian besar responden $(73,1 \%)$ memiliki asupan karbohidrat harian melebihi 100\% AKG. Hasil penelitian menunjukkan wanita dengan asupan karbohidrat berlebih memiliki risiko 4 kali mengalami obesitas sentral dibandingkan wanita dengan asupan karbohidrat tidak lebih. Konsumsi karbohidrat berlebih termasuk soft drink, makanan tinggi fruktosa dan makanan manis lainnya berhubungan dengan obesitas (Tchernof and Depres,2013). Di dalam tubuh, asupan karbohidrat yang berlebih dapat diubah menjadi lemak. Pada tahap awal, asupan karbohidrat berlebih akan disimpan dalam bentuk glikogen otot dan hati yang sewaktu waktu dapat diubah menjadi glukosa sebagaisumber energi. Perubahan karbohidrat menjadi lemak terjadi jika simpanan glikogen terus menerus naik melebihi kapasitas hati dan otot. Perubahan karbohidrat menjadi lemak dapat terjadi jika konsumsi karbohidrat berlebih secara berkelanjutan selama lebih dari 3 hari berturut turut.

Sejumlah $\quad 65 \% \quad$ responden mempunyai asupan energi berlebih $(>100 \%$ AKG). Asupan energi merupakan faktor yang berhubungan bermakna pada penelitian 
ini $(\mathrm{OR}=2,922$, CI $1,14-7,43)$. Artinya wanita dengan asupan energi berlebih memiliki risiko obesitas sentral 2,922 kali dibandingkan dengan wanita dengan asupan rendah. Hasil studi ini didukung dengan hasil studi Harikedua tahun 2014. Asupan energi yang berlebih dengan tidak diimbangi pengeluaran energi yang berlebih menyebabkan keseimbanagn energi yang positif. Kelebihan energi yang berasal dari asupan harian akan disimpan di dalam tubuh dalam bentuk lemak yang ditimbun dalam jaringan lemak di bawah kulit dan sekitar perut yang menyebabkan lingkar pinggang seseorang melebihi batas normal. Hal ini mengindikasikan bahwa jaringan lemak dibawah kulit tidak mampu lagi menyimpan lemak. Hasil suatu studi menunjukkan bahwa setiap peningkatan $1 \mathrm{kkal} / \mathrm{gram}$ kepadatan energi dalam makanan berhubungan erat dengan perubahan lingkar pinggang sebesar 0,09 cm/tahun (Du, et al,2009).

Hasil analisis bivariat riwayat obesitas sentral orang tua berhubungan dengan obesitas sentral pada responden ( $\mathrm{OR}=2,797, \mathrm{CI}:$ 1,25-6,26). Artinya wanita yang mempunyai ayah atau ibu atau kedua orang tuanya obesitas sentral akan memiliki risiko 2,797 kali mengalami obesitas dibandingkan dengan wanita yang tidak memiliki riwayat orangtua obesitas sentral.
Genetik atau keturunan berpengaruh positif terhadap obesitas dan distribusi lemak tubuh .Kemungkinan obesitas sentral diturunkan bervariasi antara 30-50\%. Gen yang diwariskan pada tiap tiap individu menentukan laju metabolik dan penggunaan energi. (Tchernof,2013; Warflaw,2007).

Hasil analisis hubungan jumlah anak yang pernah dilahirkan dengan obesitas sentral mendapatkan $\mathrm{OR}=2,965$ dengan $\mathrm{CI}=$ 1,41-6,23. Dapat disimpulkan bahwa wanita yang melahirkan anak banyak ( $\geq 3$ anak ) beresiko 2,965 kali mengalami obesitas sentral dibandingkan dengan wanita yang melahirkan sedikit anak ( $<3$ anak). Hasil penelitian ini sesuai dengan studi oleh Bhatta,et al tahun 2014. Kehamilan menyebabkan perubahan hormon yang berdampak terhadap penambahan berat lemak viseral dan jaringan lemak postpartum. Studi longitudinal selama 5 tahun pada wanita menunjukkan jumlah anak yang dilahirkan secara bermakna berhubungan dengan peningkatan lingkar pinggang (2,3 $\mathrm{cm}$ lebih besar) dan peningkatan jaringan lemak viseral $\left(18,0 \mathrm{~cm}^{2}\right.$ lebih besar) daripada wanita yang belum pernah melahirkan (Gunderson,et al,2008). Studi lain di Brazil mendapatkan wanita dengan anak 3 atau lebih memiliki peluang 1,34 kali mengalami obesitas sentral dibandingkan dengan wanita 
yang memiliki anak < dari 3 anak

(Gravena,2013)

Tabel 1. Hasil Bivariat

\begin{tabular}{|c|c|c|c|c|}
\hline \multirow{3}{*}{$\begin{array}{l}\text { Variable } \\
\text { Umur }\end{array}$} & \multicolumn{2}{|c|}{ Prevalensi obesitas sentral } & \multirow{2}{*}{\multicolumn{2}{|c|}{$\begin{array}{c}\text { OR }(95 \% \mathrm{CI}) \\
\text { p value }\end{array}$}} \\
\hline & \multirow{3}{*}{$\begin{array}{l}\text { Ya (\%) } \\
60,8\end{array}$} & \multirow{3}{*}{$\begin{array}{l}\text { Tidak (\%) } \\
39,2\end{array}$} & & \\
\hline & & & \multirow{3}{*}{$5,505(2,3-13,09)$} & \multirow{3}{*}{$0,000^{*}$} \\
\hline Desawa akhir & & & & \\
\hline Dewasa awal & 22,9 & 78,0 & & \\
\hline \multicolumn{5}{|c|}{ Tingkat pendidikan } \\
\hline Rendah & 39,9 & 60,7 & \multirow{2}{*}{$1,865(0,95-1,97)$} & \multirow{2}{*}{1,133} \\
\hline Tinggi & 54,7 & 45,3 & & \\
\hline \multicolumn{5}{|c|}{ Tingkat pengetahuan gizi } \\
\hline Kurang & \multirow[t]{2}{*}{51.7} & \multirow[t]{2}{*}{48,3} & \multirow[t]{2}{*}{$1,389(0,68-2,85)$} & \multirow[t]{2}{*}{0,476} \\
\hline Baik & & & & \\
\hline \multicolumn{5}{|c|}{ Tingkat pekerjaan } \\
\hline Ringan & \multirow[t]{2}{*}{53,1} & \multirow[t]{2}{*}{46,9} & \multirow[t]{2}{*}{$1,626(0,78-3,35)$} & \multirow[t]{2}{*}{0,256} \\
\hline Berat & & & & \\
\hline \multicolumn{5}{|c|}{ Status pernikahan } \\
\hline $\begin{array}{l}\text { Belum } \\
\text { menikah/cerai }\end{array}$ & 30,0 & 50,9 & \multirow[t]{2}{*}{$2,250(0,55-9,15)$} & \multirow[t]{2}{*}{0,329} \\
\hline Menikah & 49,1 & 70,0 & & \\
\hline Aktivitas fisik & & & & \\
\hline Kurang & 56,2 & 43,8 & $0,467(0,22-0,97)$ & 0,062 \\
\hline Cukup & 37,5 & 62,5 & & \\
\hline Asupan energy & & & & \\
\hline Lebih & 68,0 & 32,0 & $2,922-(1,14-7,43)$ & $0,037 *$ \\
\hline Tidak lebih & 42,1 & 57,9 & & \\
\hline Asupan protein & & & & \\
\hline Tidak kurang & 47,6 & 52,4 & $1,007(0,47-2,13)$ & 1,000 \\
\hline Kurang & 47,4 & 52,6 & & \\
\hline Asupan lemak & & & & \\
\hline Lebih & 68,9 & 31,1 & $6,484(2,92-14,4)$ & $0,000 *$ \\
\hline Tidak lebih & 25,4 & 74,6 & & \\
\hline Asupan karboh & & & & \\
\hline Lebih & 73,1 & 26,9 & $4,00(1,53-10,4)$ & $0,006^{*}$ \\
\hline Tidak lebih & 40,4 & 59,6 & & \\
\hline Asupan serat & & & & \\
\hline Kurang & 43,5 & 56,5 & $0,720(0,35-1,48)$ & 0,476 \\
\hline Tidak kurang & 51,7 & 48,3 & & \\
\hline Riwayat obesita & & & & \\
\hline Ada & 64,9 & 35,1 & $2,797(1,25-6,26)$ & $0,019 *$ \\
\hline Tidak ada & 39,8 & 60,2 & & \\
\hline Jumlah anak ya & & & & \\
\hline$\geq 3$ anak & 61,4 & 38,6 & $2,965(1,41-6,23)$ & $0,007 *$ \\
\hline$<3$ anak & 34,9 & 65,1 & & \\
\hline Status menopau & & & & \\
\hline Tidak & 55,3 & 44,7 & $1,57(0,73-3,42)$ & 0,336 \\
\hline Menopause & 44,4 & 55,6 & & \\
\hline Penggunaan ko & & & & \\
\hline $\mathrm{Ya}$ & 49,3 & 50,7 & $0,822(0,39-1,73)$ & 0,741 \\
\hline Tidak & 44,4 & 55,6 & & \\
\hline
\end{tabular}

Ket: *bermakna 
Tabel 2. Hasil Akhir Pemodelan Multivariat

\begin{tabular}{llll}
\hline Variabel & p-value & Nilai $\operatorname{Exp}(\mathbf{B})$ & $\mathbf{9 5 \%}$ CI \\
\hline Umur & 0,006 & 8,156 & $1,8-35,9$ \\
Asupan lemak & 0,001 & 9,492 & $2,5-35,1$ \\
Asupan karbohidrat & 0,038 & 6,270 & $1,1-35,5$ \\
Riwayat obesitas sentral orang tua & 0,005 & 5,722 & $1,6-19,5$ \\
Aktivitas fisik & 0,999 & 2,167 & 0,0 \\
Tingkat pekerjaan & 0,999 & 0,000 & 0,0 \\
Asupan protein & 0,812 & 1,182 & $0,29-4,6$ \\
Asupan serat & 0,685 & 1,276 & $0,3-4,14$ \\
Asupan energi & 0,651 & 0,635 & $0,8-4,54$ \\
Tingkat pendidikan & 0,440 & 0,623 & $0,1-2,07$ \\
Jumlah anak yang dilahirkan & 0,245 & 2,018 & $0,61-6,6$ \\
Status menopause & 0,204 & 0,435 & $0,1-1,57$ \\
\hline
\end{tabular}

Hasil akhir analisis multivariat didapatkan nilai OR (Exp B) variabel asupan lemak paling tinggi $(9,492)$ artinya asupan lemak mempunyai pengaruh paling besar terhadap kejadian obesitas sentral . Secara statistik responden dengan asupan lemak berisiko 9,492 kali lebih besar menderita obesitas sentral dibandingkan kelompok responden dengan asupan lemak yang tidak berlebih.

Hasil penelitian ini sejalan dengan penelitian di Afrika yang menunjukkan asupan energi dan lemak lebih tinggi di kelompok perempuan desa dibandingkan kelompok perempuan kota (Mennen, et al,2000). Secara teori daerah urban atau perkotaan mempunyai risiko obesitas sentral lebih tinggi karena makanan tinggi lemak dan gula lebih banyak variasinya dan dalam jumlah melimpah. Hal ini tidak sepenuhnya berlaku karena telah terjadi pergeseran di daerah pedesaan. Masyarakat pedesaan yang semula mengkonsumsi makanan tinggi serat dan karbohidrat kompleks kini terbiasa mengkonsumsi tinggi lemak dan gula karena makanan tersebut semakin mudah diperoleh. Kebiasaan ini akan memicu kenaikan berat badan dan mengarah pada obesitas sentral (Swinburn,et al,2004). Data food recall pada penelitian ini menunjukkan makanan yang digoreng dan bersantan menjadi penyumbang lemak yang cukup besar dalam asupan harian. Makanan berlemak cenderung mempunyai rasa yang enak dan memungkinkan makan makanan terseut dalam jumlah yang berlebih. Selain itu makanan berlemak mempunyai tingkat kepadatan energi yang tinggi sehingga dapat memungkinkan terjadi keseimbangan energi yang positif jika mengkonsumsi dalam jumlah yang berlebih. Studi terkait tingkat kepadatan energi dengan asupan harian 
menunjukkan hubungan yang positif dengan ukuran lingkar pinggang seseorang.Tingkat kepadatan energi yang rendah dalam asupan harian responden terbukti mampu mencegah obesitas abdominal. Setiap peningkatan 1kkal/gram kepadatan energi dalam makanan berhubungan erat dengan perubahan lingkar pinggang sebesar 0,09 $\mathrm{cm} /$ tahun (Du,et al,2009).

\section{SIMPULAN DAN SARAN}

Asupan lemak merupakan faktor dominan terhadap kejadian obesitas sentral di

\section{DAFTAR PUSTAKA}

Brown,J.E.,Isaacs,J.S., Krinke,U.B.\&Lechtenberg,E.,2011. Nutrition Through the Life Cycle. USA;Wadsworth

Bhatta,M.P.,Assad,L., and Shakya,S., 2014. SocioDemographic and Dietary Factors Associated with Excess Body Weight and Abdominal Obesity among Resettled Bhutanase refugee Women in Northeast Ohio, United States. International Journal of Environment and Research,Issue 11,pp.6639-6652.

Dagenais,G.R.,Yi,Q.,Mann,J.F.E.,Bosch,J., Pogue,J.,and Yusuf,S., 2004. Prognostic Impact of Body Weight and Abdominal Obesity in Women and Men with Cardiovascular Diasesase. American Heart Journal, 149(1),pp.54-60.

Direk,K., Cecelja,M., Astle,W., Chowienczyk,P., Spector,T.D.,and Falchi,M., 2013. The Relationship between DXA-Based and Anthropometric Measures of Visceral Fat and Morbidity in Women. BMC Cardiovascular Disorder,13(25),pp.1-13.

Du,H., and Ginder,V., 2009. Dietary Energy Density in Relation to Subsequent Changes of Weight and Waist Circumference in European Men and Women. Energy Density on Waist Change,4(4),pp.1-8. kelompok perempuan dewasa di desa ini. Perlu dilakukan program pengendalian obesitas sentral dengan melibatkan instansi terkait seperti Puskesmas dengan memberikan edukasi gizi seimbang agar dapat meningkatkan aktivitas fisik dan mengkonsumsi makanan seimbang dengan membatasi makanan yang berlemak atau berenergi tinggi. Perlu diberikan sosialisasi program Keluarga Berencana (KB) agar dapat merencanakan dan membatasi jumlah anak.

Gravena,A.A.F, Brischiliari,S.C.R., Lopes,T.C.R., Agnolo,C.M.D.,Carvalho,M.D.B., Pelloso,S.M., 2013. Excess Weight and Abdominal Obesity in Postmenopausal Brazilian Women: A Population Based Study. Biomedcentral Women's Health.pp.17.

Gunderson,E.P., Jacobs,D.R., and Chiang,V., 2008. Childbearing is Associated with Higher Incidence of the Metabolic Syndrome amongh Women of Reproductive Age Controlling for Measurements Before Pregnancy: the CARDIA Study. American Journal of Obstetric and Gynocology, Issue 201,pp.177-179.

Harikedua,V.T. dan Tando,N.M., 2012. Aktivitas Fisik dan Pola Makan dengan Obesitas Sentral pada Tokoh Agama di Kota Menado. Gizi Indonesia.4(1),pp.289-298.

Hwang,M.,J.,Chung,W.,S.,Ghallager,D.and

Kim,D.,2008. How Useful is Waist Circumference for Assessment of Abdominal obesity in Korean Pre Menopausal Women during Weight Loss? Asia Pasific Journal of Clinical Nutrition,17(2),pp.229-234.

IDF,2006. Diabetes Voice. The Metabolic Syndrome, 1 May,51 (Special Issue),pp.11-15.

Kantachuvessiri.A., Sirivichayakul,C. \& KaewKungwal,J.,2005. Faktors Associated with Obesity Among Workers in 
J.Gipas, November 2019, Volume 3 Nomor 2 ISSN 2599-0152 eISSN 2599-2465 http://jos.unsoed.ac.id/index.php/jgps

Metropolitan Waterworks Authority. South East Asian Journal 36(4),pp.1057-1065

Kemenkes, 2013. Hasil Riset Kesehatan Dasar 2013 Provinsi Jawa Tengah. Jakarta:Kementrian Kesehatan Republik Indonesia.

Kemenkes, 2013. Hasil Riset Kesehatan Dasar 2013. Jakarta:Kementrian Kesehatan Republik Indonesia.

Kemenkes, 2018. Hasil Riset Kesehatan Dasar 2018. Badan Penelitian dan Pengembangan Kesehatan. Kementrian Kesehatan Republik Indonesia.

Mennen,L.I.,Mbanya,J.C.,Cade,J.,Balkau,B.,Sharma, S.,Chungong,S., and Cruckshank,J.K.,2005. The Habitual Diet in Rural and Urban Cameroon.European Journal of Clinical Nutrition.Issue 54,pp.150-154.

Sugiharti,S.,Hadi,H.,and Julia,M.,2005.Hormonal Contraception as a Risk Factor for Obesity. Medical Journal Indonesia,14(3),pp.163169.

Swinburn,B.A.,Caterson,I.,Seidell,J.C.,and James,W,P,T.,2004. Diet,Nutrition and the Prevention of Excess Weight Gain and
Obesity. Public Health Nutrition,7(1A),pp.123-146.

Tchernof,A.\&Depres,J.P.,2013.Pathophysiology of Human Visceral Obesity: An Update. Physiologycal Riview,Issues 93,pp.359-404

Tzotzas,T., Vlahavas,G., Papadopoulou,S.K., Kapantais,E. ,Kaklamanou,D.,2010. Marital Status and Educational Level Associated to Obesity in Greek adults: Data from the National Epidemiologycal Survey. BioMedCentral Public Health,10(732).pp.18.

Wardlaw,G.M. and Hampl,J.S.,2007. Perspectives in Nutrition.7th .New York: McGraw-Hill.

WHO, 1981.Research on the Menopause, Geneva: World Health Organization.

WHO, 2008. Waist Circumference and Waist-Hip Ratio: Report of WHO Expert Consultation, Geneva,8-11 Desember 2008, Geneva: WHO Document Production Services.

WHO ,2011. Global Physical Activity Questionnaire (GPAQ). Geneva: WHO.

WHO, 2011. Global Status Report on NonCommunicable Disease 2014. Geneva: WHO Press. 